\title{
A clinicopathological study of pleural effusion with special reference to malignant aetiology in a tertiary care hospital in West Bengal
}

\author{
Mandal S. ${ }^{1 *}$, Banik T. ${ }^{2}$, Barman R. ${ }^{3}$, Mandal A. ${ }^{4}$, Kumar Bar P. ${ }^{5}$ \\ DOI: https://doi.org/10.17511/ijmrr.2019.i04.03 \\ 1* Saikat Mandal, Demonstrator, Department of Pathology, Malda Medical College, Malda, West Bengal, India. \\ 2 Tarak Banik, Assistant Professor, Department of Pathology, Malda Medical College, Malda, West Bengal, India. \\ 3 Rina Barman, Assistant Professor, Department of Pathology, Malda Medical College, Malda, West Bengal, India. \\ ${ }^{4}$ Animesh Mandal, Assistant Professor, Department of Chest Medicine, Malda Medical College, Malda, West Bengal, India. \\ 5 Prasenjit Kumar Bar, Assistant Professor, Department of Pathology, Malda Medical College, Malda, West Bengal, India.
}

Background: Pleural effusion has varied aetiological factors. It constitutes one of the major causes of morbidity in India as well in other parts of world. Because of the various aetiologies that can cause pleural effusion, itoften present a diagnostic problem, even after extensive investigations. Objective: In this study, authors aimed to identify the common aetiologies causing pleural effusion and their clinical profile in a tertiary care hospital. Materials and Methods: A hospital based crosssectional study is conducted over a period of one year in tertiary care hospital in West Bengal. 150 patients of pleural effusion above $10 \mathrm{yrs}$ of age were studied. Clinico-pathological, radiological, hematological and biochemical parameters were documented. Results: The most common cause pleural effusion in this study was tuberculosis $(64.67 \%)$, followed by malignancy $(14.67 \%)$, parapneumonic effusion $(7.33 \%)$, cardiac failure $(5.33 \%)$ and other minor causes. It was commonly seen in male $(70 \%)$. The occurrence of tubercular pleural effusion was maximum in the age group 31-40 years. Right-sided effusions were more common. Pleural fluid cytology and adenosine deaminase played a pivotal role in the diagnosis of tubercular pleural effusion. Conclusion: The present study highlights tuberculosis as the common causative factor for pleural effusion, labels lung carcinoma as the most common cause of malignant pleural effusion, and defines the clinicopathological, biochemical and imaging characteristics of different aetiologies of pleural effusion.

Keywords: Pleural effusion, Tubercular effusion, Malignant effusion

\section{Corresponding Author}

Saikat Mandal, Demonstrator, Department of Pathology, Malda Medical College, Malda, West Bengal, India.

Email: saikat1607@gmail.com
How to Cite this Article

To Browse

Mandal S, Banik T, Barman R, Mandal A, Bar PK. A clinicopathological study of pleural effusion with special reference to malignant aetiology in a tertiary care hospital in West Bengal. Int J Med Res Rev. 2019;7(4):266-272.

Available From

https://ijmrr.medresearch.in/index.php/ijmrr/article/ view/1068
Manuscript Received 2019-06-20

Conflict of Interest No
Review Round 1 2019-06-30

Funding Nil
Review Round 2 2019-07-04

Ethical Approval Yes
Review Round 3

Plagiarism X-checker $9 \%$

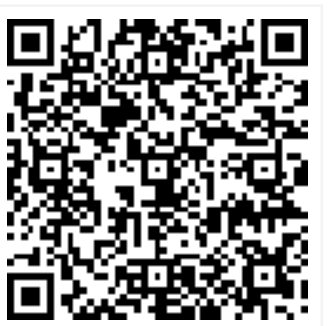

(c) 2019 by Saikat Mandal, Tarak Banik, Rina Barman, Animesh Mandal, Prasenjit Kumar Bar and Published by Siddharth Health Research and Social Welfare Society. This is an Ópen Access article licensed under a Creative Commons Attribution 4.0 International License hittps://creativecommons.org/licenses/by/4.0/ unported [CC BY 4.0]. 


\section{Introduction}

Pleural effusion is an excess fluid that accumulates between the two pleural layers [1]. The aetiologic spectrum of pleural effusion depends on the geographical region and the local incidence of different diseases that cause pleural effusions. In developed countries the common causes of pleural effusions in adults are cardiac failure, malignancy and pneumonia $[2,3]$, whereas in developing countries tuberculosis and parapneumonic effusions (PPE) are more prevalent [4-7]. Malignant pleural effusion (MPE) is one of the most challenging pleural disorders to manage, given the paucity of highquality evidence and the heterogenecity of practice worldwide [8,9]. Between $30 \%$ and $50 \%$ of all patients with metastatic malignancies will have pleural involvement at autopsy, and approximately half of these will have pleural effusions, which range from insignificant to massive [10]. There remains still a gap in the knowledge and understanding of aetiological causes and clinical profile of pleural effusion as there is limited studies in different geographical location. Authors aimed this study to explore the aetiology and clinical profile of patients with pleural effusion with emphasis on malignant aetiology attending our institute.

\section{Objectives}

The objective of this study was to explore the aetiopathology of pleural effusion in the patients who were admitted to a tertiary care hospital in West Bengal. The objectives of this present work is to study the distribution of aetiology of pleural effusion, alteration of blood and pleural fluid parameters in patients with pleural effusion, the imaging findings in patients admitted with pleural effusion and the etiological causes of malignant pleural effusion.

\section{Materials and Methods}

Study type: Cross sectional hospital based observational study.

Study design: Prospective cohort study.

Study setting/area, population and period: The study was performed in patients attending in Outpatient Department (OPD) and Indoor Department of Chest Medicine in Malda Medical College and Hospital from Malda and its surrounding districts, during the period from 1st March 2017 to 28th February 2018 (One year).

\section{Sampling}

Selection of cohort of patients with pleural effusion: A total of 180 patients were selected. Out of 180 selected pleural effusion patients, 150 patients fulfil the inclusion and exclusion criteria and they were taken into the present study.

Sampling technique: Consecutive non probability technique used, consensus sampling.

\section{Inclusion criteria}

01. Patients of both gender of more than 10 years of age with clinical and radiological features of pleural effusion and ultimately confirmed by pleurocentesis presented to OPD and Indoor Department of Chest Medicine.

02. Patients who had given valid consent.

\section{Exclusion criteria}

01. Patients already on treatment

02. Hemodynamically unstable patients.

03. Patients with hemothorax and chylothorax

04. Uncooperative patients and inadequate sample.

Detailed clinico-radiological examination and routine laboratory examination done like haemoglobin, total and differential WBC count, erythrocyte sedimentation rate (ESR), random blood sugar, serum proteins, urine and sputum examination and tuberculin test are carried out in all patients. A plain chest $X$ ray PA view was taken prior to pleural fluid aspiration to rule out complications.

Additional films, ultrasonography and CT scan (Figure 1A) were done whenever needed. Pleural fluid analysis were done for protein, sugar, total cell count and cell type, Gram's stain, ZN stain, culture and sensitivity and adenosine deaminase (ADA).

Method of confirmation of malignant aetiology: Ten millilitres of fresh pleural sample was divided into two equal parts of five millilitres each. One part was subjected to the conventional smear cytology technique and the other part for the cell block technique. Thus, the same sample was evaluated for a comparative study.

The conventional smear technique: The $5 \mathrm{ml}$ sample was centrifuged at $2500 \mathrm{rpm}$ for 15 minutes. A minimum of 2 thin smears were prepared from the sediment. One smear was prepared after air drying and it was stained with the May-Grünwald-Giemsa stain. 
The other smear was immediately fixed in $95 \%$ alcohol and it was stained with the Papanicolaou stain and Hematoxylin \& Eosin (H\&E) stain (Figure 1B).

The cell block technique: Cell block done with the remaining $5 \mathrm{ml}$ sample by using AAF fixative (95\% ethyl alcohol $34 \mathrm{ml}+$ formalin $4 \mathrm{ml}$ +Glacial acetic acid $2 \mathrm{ml}$ ). The cell pellet remaining after preparing smears is mixed with thrice the volume of AAF fixative and one or two drops of the supernatant fluid and centrifuged for 10 minutes at $2000 \mathrm{rpm}$. Then the cell button is re-suspended in AAF fixative and centrifuged for 10 minutes at $3000 \mathrm{rpm}$. The centrifugedtube is taken aside for 4-6 hours, after which the cell button is scraped out and wrap in lens paper and processed along with other routine biopsy specimens. After paraffin embedding, $5 \mu$ thickness sections were cut from this cell button and stained with the H\&E stain (Figure 1C).

Table-1: Distribution of cases according to aetiology.

\begin{tabular}{|c|c|c|c|c|c|c|c|}
\hline Effusion type & Aetiology & Rt. & Lt. & $\mathrm{B} / \mathrm{L}$ & M $(\%)$ & $F(\%)$ & Number of cases $(\%)$ \\
\hline \multirow[t]{7}{*}{ Exudative effusion Number: $137(91.33 \%)$} & Tuberculosis & 64 & 33 & 0 & $69(46)$ & $28(18.67)$ & $97(64.67)$ \\
\hline & Malignant & 15 & 7 & 0 & $14(9.33)$ & $8(5.34)$ & $22(14.67)$ \\
\hline & Parapneumonic & 7 & 4 & 0 & $6(4)$ & $5(3.33)$ & $11(7.33)$ \\
\hline & Empyema & 1 & 2 & 0 & $3(2)$ & 0 & $3(2.00)$ \\
\hline & Pancreatitis & 1 & 0 & 0 & $1(0.67)$ & 0 & $1(0.67)$ \\
\hline & Rheumatic arthritis & 1 & 0 & 0 & $1(0.67)$ & 0 & $1(0.67)$ \\
\hline & Undiagnosed & 0 & 1 & 1 & $2(1.33)$ & 0 & $2(1.33)$ \\
\hline \multirow[t]{5}{*}{ Transudative effusion Number: $13(8.67 \%)$} & Cardiac failure & 2 & 1 & 5 & $4(2.67)$ & $4(2.66)$ & $8(5.33)$ \\
\hline & Cirrhosis of liver & 1 & 1 & 0 & $2(1.33)$ & 0 & $2(1.33)$ \\
\hline & Chronic renal failure & 0 & 0 & 2 & $2(1.33)$ & 0 & $2(1.33)$ \\
\hline & Hypoproteinaemia & 0 & 0 & 1 & $1(0.67)$ & 0 & $1(0.67)$ \\
\hline & Total & 92 & 49 & 9 & $105(70)$ & $45(30)$ & $150(100)$ \\
\hline
\end{tabular}

Special stains like the Periodic Acid Schiff (PAS) were performed wherever they were necessary.

After Confirmation of malignant aetiology, bronchoscopy, CT guided FNAC, core biopsy (Figure 1D), Pelvic USG with guided FNAC were done to confirm primary lesion.

Data analysis: All data collected were tabulated on a grand chart and analysed using chart, diagram by a statistical software SPSS version 22 .

Statistical methods: Percentage, prevalence were calculated using SPSS version 22 software

\section{Result}

A total of 150 cases of diagnosed pleural effusion was taken in the present study maintaining the inclusion and exclusion criteria. Among all cases ( $n$ -150) the exudative type was far more commonthan transudative one ( $91.33 \%$ vs. $8.67 \%)$. 
As shown in table 2 , it is clearly evident that male patients outnumbered female patients by $40 \%$ (male $70 \%$ vs. female $30 \%$ ). Majority of patients were in age group of 31 to 40 years (44 patients, $29.34 \%$ of study population) out of which male were 30 and rest were female patients. The second most common age group was 41 to 50 years comprising of $23.33 \%$ (35 cases) of study population.

\section{Table-3: The causes of malignant pleural} effusion.

\begin{tabular}{|c|c|c|}
\hline Types & & Number of cases $(\%)$ \\
\hline \multirow[t]{4}{*}{ Lung carcinoma } & Adenocarcinoma & \multirow[t]{4}{*}{$11(50)$} \\
\hline & Squamous cell carcinoma & \\
\hline & Undifferentiated/large cell & \\
\hline & Small cell carcinoma & \\
\hline \multicolumn{2}{|l|}{ Breast } & $3(13.64)$ \\
\hline \multicolumn{2}{|l|}{ Gynaecological } & $2(9.10)$ \\
\hline \multicolumn{2}{|l|}{ Gastrointestinal } & $1(4.54)$ \\
\hline \multicolumn{2}{|l|}{ Lymphoma } & $1(4.54)$ \\
\hline
\end{tabular}

\begin{tabular}{|l|l|}
\hline Mesothelioma & $1(4.54)$ \\
\hline Unknown primary & $3(13.64)$ \\
\hline
\end{tabular}

Table no. 3 shows that the most common cause of malignant pleural effusion (MPE) was lung carcinoma accounting for half of all cases of malignancy (11 out of 22 cases)among them adenocarcinoma of lung was the most frequent, whereas undifferentiated/large cell carcinoma was least in frequency. Two cases each of squamous cell carcinoma and small cell carcinoma detected in the present study. Among other causes of MPE, breast malignancy diagnosed in threecases (13.64\%), gynaecological malignancy in two cases (9.10\%), gastrointestinal malignancy, lymphoma and mesothelioma each had single cases. In three cases primary site cannot be diagnosed by using our formulated diagnostic approach. History of smoking was present in 88 subjects (58.66\%), among which male were 84 and the rest were female. Those who had MPE, $63.63 \%$ (14 patients) had history of smoking.

Table-4: Cellular and biochemical Analysis of Pleural fluid.

\begin{tabular}{|c|c|c|c|c|c|c|c|c|}
\hline \multirow[t]{2}{*}{ Diagnosis } & \multicolumn{3}{|c|}{ Total count/mm3 } & \multicolumn{3}{|c|}{ Predominant cell type } & \multicolumn{2}{|c|}{ ADA value(IU/L) } \\
\hline & $0-250$ & $251-1000$ & $>1000$ & Lymphocyte & Polymorph & $<30$ & $31-60$ & $>60$ \\
\hline Tuberculosis & 33 & 61 & 3 & 97 & 0 & 8 & 32 & 57 \\
\hline Malignant & 2 & 12 & 8 & 18 & 4 & 20 & 2 & 0 \\
\hline Parapneumonic & 0 & 0 & 11 & 0 & 11 & 9 & 2 & 0 \\
\hline Empyema & 0 & 0 & 3 & 0 & 3 & 0 & 2 & 1 \\
\hline Pancreatitis & 0 & 1 & 1 & 1 & 0 & 1 & 0 & 0 \\
\hline Rheumatic arthritis & 0 & 1 & 0 & 1 & 0 & 0 & 1 & 0 \\
\hline Cardiac failure & 7 & 1 & 0 & 1 & 0 & 7 & 1 & 0 \\
\hline Cirrhosis of liver & 2 & 0 & 0 & 1 & 0 & 2 & 0 & 0 \\
\hline Chronic renal failure & 2 & 0 & 0 & 1 & 0 & 2 & 0 & 0 \\
\hline Hypoproteinaemia & 2 & 0 & 0 & 2 & 0 & 1 & 0 & 0 \\
\hline Undiagnosed & 0 & 2 & 0 & 2 & 0 & 2 & 0 & 0 \\
\hline
\end{tabular}

Table no. 4 shows that 61 patients $(62.88 \%)$ with tuberculous effusion had total cell count between 251- 1000 while 33 (34.02\%) patients had total cell count between 0-250 and only three cases of tuberculous aetiology had cell count more than 1000 cells. In cases of MPE 12 patients (54.54\%) had cell count ranging from 251 to 1000 and 8 $(36.36 \%)$ patients had $>1000$ cell count. Among parapneumonic effusion, all (100\%) patients had total count between 1001-5000. All cases of tuberculous effusion (100\%) and majority malignant effusion (81.81\%) had predominant lymphocytes while all patients with parapneumonic effusion and empyema thoracis had predominant polymorphs.
Majority of tuberculous effusion (58.76\%) had ADA value $>60 \mathrm{IU} / \mathrm{L}$ whereas majority of MPE had low ADA value $(<30 I U / L)$.

Sputum for AFB with ZN stain was done in all cases of pleural effusions. It was positive in one patient, who later diagnosed as a case of broncho-pleural fistula. In other group it was negative in all cases. Pleural fluid cytology for malignant cells was done in all pleural effusion patients. It was suspicious for atypical cells in all 22 patients out of 22 patients of malignant pleural effusion. Pleural fluid for Gram's stain and culture sensitivity was done in all pleural effusion patients. 


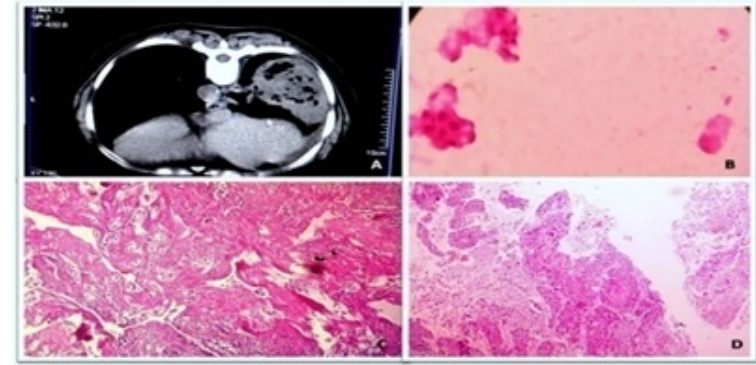

Figure 1A: Photograph showing mass lesion in computed tomography (CT); Figure 1B: Photomicrograph showing atypical cells in pleural fluid, H\&E stain X400; Figure 1C: Photomicrograph of cell block showing clusters of malignant epithelial cells, H\&E stain X100; Figure 1D: Photomicrograph of core needle biopsy showing squamous cell carcinoma (moderately differentiated) of lung, H\&E stain X100

\section{Discussion}

The most common aetiology in the present study is tuberculosis $(64.67 \%)$, followed by malignant pleural effusion(14.67\%) and parapneumonic effusion $(7.33 \%)$. The other aetiologies in the same order are cardiac failure $(5.33 \%)$, empyema (2\%), cirrhosis of liver, chronic renal failure and undiagnosed (each1.33\%), pancreatitis, rheumatic arthritis and hypoproteinaemia (each $0.67 \%$ ). This epidemiological result corroborates closely with the findings of Jindal [11] Valdés [12].

Tuberculosis was also the leading cause of pleural effusion ina study conducted by Maikap MK [13], while world wide CCF is the most common cause of pleural effusion [14]. But a study conducted in respiratory intensive care set up by Chinchkar $\mathrm{N} \mathrm{J}$ and co workers found malignancy to be the most frequent cause of pleural effusion [15]. The present study showed lesser frequency of transudative effusion may be due to the fact that it was conducted at chest medicine department of a teaching hospital where most of the cases of cardiac failure, cirrhosis, hypoproteinaemia may attended in the cardiology or general medicine department after segregation from general outpatient department or emergency room.

Majority of cases of pleural effusion were males as compared to females in the present study $(70 \%$ vs. $30 \%$ ) with male: female ratio $2.33: 1$. The male preponderance is similar among tuberculosis and MPE group also.
Sharma SK et [16] al and Maikap M K et al [13] also found similar male majority in their previous studies. In the present study, the patients with pleural effusion were found in all age groups ranging from 11 years boy as the youngest subject and 71 years aged male was the eldest and patients aged between 31 and 40 represent the largest group $(29.34 \%)$. This finding was in concordance with the study of Parikh P and co-researchers [17]. One previous study found majority of their cases between 21 and 40 year of age [18] another study found majority of their cases $(29.6 \%)$ below 20 years of age [19]. In the present study revealed that pleural effusions were predominantly observed in the right side $(61.33 \%)$ which corroborates with a few previous studies $[13,17,20]$. Majority of the cases in this study had predominantly lymphocyte rich pleural effusion. $90.66 \%$ cases had lymphocyte count of $80 \%$ or more. Predominantly polymorphs are commonly found in PPE, empyema, pleural effusion due to pancreatic disease, and rheumatoid arthritis [21]. In the present study, 14 cases $(9.33 \%)$ were found to have predominantly polymorphs in the pleural fluid, out of which 11 were in due to parapneumonic effusion and three due to empyema thoracis. Many authors reported that values of ADA were significantly higher in tubercular effusions $[22,23]$. In the present study, $32.98 \%$ of tubercular pleural effusion had pleural fluid ADA level in the range of 31-60 IU/L and significantly $58.76 \%$ patients had above $60 \mathrm{IU} / \mathrm{L}$.

MPE was found in $14.67 \%$ of cases which was quite similar to different research articles published previously like F Y Khan et al (15.55\%) [23], Maikap et al (14\%) [13] and Chinchkar NJ (24\%) [15]. Lung carcinoma was the most common cause of MPE, among which adenocarcinoma was the most common subtype which corroborates with another study conducted in Indian scenario by $\mathrm{V}$ Noronha and co-workers [25]. Three out of 22 cases remained undetected for primary site even on through investigations. In these cases immunohistochemistry panels may be helpful which may include markers of lung, breast, kidney, melanoma and germ cell tumors. An obvious limitation of the study was that the number of patients is 150 only and duration is only one year, which could limit the general applicability of our findings to the larger community setup and a possible selection bias, as patients with advanced malignancy may have been referred directly for palliative care, without further investigations. 
In the present study, diagnosed cases of pleural effusion that might be on conservative management before enrolment were included. So, effect of previous treatment, which may affect our diagnostic workup and differential diagnosis, were not taken into account.

\section{Conclusion}

From this hospital based cross-sectional study; it can be concluded that, most common cause of pleural effusion in a tertiary hospital setting is tuberculosis, followed by malignant pleural effusion and parapneumonic effusion. So in a community set up, implementation of strategies to decrease the burden of tuberculosis is required, which would in turn lead to tubercular pleural effusion.

The present study also showed most common cause of malignant effusion is lung carcinoma, followed by breast, unknown primary and gynaecological malignancies. Significant improvement of diagnostic accuracy has been observed by using cell block and core needle biopsy in addition to conventional smears cytology. The study was conducted in a tertiary care hospital with limited resources. Thus authors formulated a convenient protocol to reach at an aetiological diagnosis of cases of pleural effusion in centres with a handful of resources.

\section{Contribution by authors}

01. Prasenjit Kumar Bar - Concept designing and conducting the study \& writing the manuscript.

02. Saikat Mandal, Dr TarakBanik and Dr Rina Barman- Conducting the study and writing the manuscript.

03. Dr Animesh Mandal- Guiding the study procedure, statistical analysis and preparing the manuscript suitable for publication.

\section{Reference}

01. Wong CL, Holroyd-Leduc J, Straus SE. Does this patient have a pleural effusion?. JAMA. 2009;301(3)309-17.

DOI: 10.1001/jama.2008.937 [Crossref]

02. Light RW. Clinical practice, Pleural effusion. N Engl J Med. 2002;346(25)1971-7.

DOI: $10.1056 /$ NEJMcp010731 [Crossref]
03. Marel M, Zrůtová M, Štasny B, Light RW. The incidence of pleural effusion in a well-defined region- Epidemiologic study in central Bohemia. Chest. $1993 ; 104(5) 1486-9$.

DOI: $10.1378 /$ chest.104.5.1486 [Crossref]

04. Afful B, Murphy S, Antunes G, Dudzevicius V. The characteristics and causes of pleural effusions in Kumasi Ghana- a prospective study. Trop Doct. 2008;38(4)219-20.

DOI: $10.1258 /$ td.2007.070275 [Crossref]

05. Koffi N, Aka-Danguy E, Kouassi B, Ngom A, Blehou DJ. Etiologies of pleurisies in African milieu- Experience of the Cocody Pneumology department (Abidjan-Côte d'Ivoire). Rev Pneumol Clin. 1997;53(4)193-6.

DOI: RP-10-1997-53-4-0761-8417-101019-ART67 [Crossref]

06. Al-Qorain A, Larbi EB, Al-Muhanna F, Satti MB, Baloush A, Falha K. Pattern of pleural effusion in Eastern Province of Saudi Arabia- a prospective study. East African Medical Journal. $1994 ; 71(4) 246-249$.

[Crossref]

07. Al-Alusi F. Pleural effusion in Iraq- a prospective study of 100 cases. Thorax. 1986;41(6)492-3. DOI: $10.1136 /$ thx.41.6.492 [Crossref]

08. Heffner JE, Klein JS. Recent advances in the diagnosis and management of malignant pleural effusions. Mayo Clin Proc. 2008;83(2)235-50. DOI: $10.4065 / 83.2 .235$ [Crossref]

09. Azzopardi M, Porcel JM, Koegelenberg CF, Lee YC, Fysh ET. Current controversies in the management of malignant pleural effusions. Semin Respir Crit Care Med. 2014;35(6)723-31. DOI: $10.1055 / \mathrm{s}-0034-1395795$ [Crossref]

10. Fitzgerald DB, Koegelenberg CFN, Yasufuku K, Lee YG. Surgical and non-surgical management of malignant pleural effusions. Expert Rev Respir Med. 2018;12(1)15-26.

DOI: $10.1080 / 17476348.2018 .1398085$ [Crossref]

11. Jindal SK. Textbook of Pulmonary and Critical Care Medicine. 1st ed, New Delhi- Jaypee Brothers Medical Publishers (P) Ltd. Vol 2;2011. [Crossref] 
12. Valdes L, Alvarez D, Valle JM, Pose A, San Jose $E$. The etiology of pleural effusions in an area with high incidence of tuberculosis. Chest. $1996 ; 109(1) 158-62$.

DOI: $10.1378 /$ chest.109.1.158 [Crossref]

13. Maikap MK, Dhua A, Maitra MK. Etiology and clinical profile of pleural effusion. Int J Med Sci Pub Health. 2018;7(4)316-22.

DOI: $\quad$ 10.5455/ijmsph.2018.0101931012018 [Crossref]

14. Light RW. Clinical manifestations and useful tests. Pleural Dis. 1995;10(4)42-86.

DOI: $10.1183 / 09031936.97 .10020476$ [Crossref]

15. Chinchkar NJ, Talwar D, Jain SK. A stepwise approach to the etiologic diagnosis of pleural effusion in respiratory intensive care unit and short-term evaluation of treatment. Lung India. 2015;32(2)107-15.

DOI: $\quad 10.4103 / 0970-2113.152615$ [Crossref]

16. Sharma SK, Suresh V, Mohan A, Kaur P, Saha P, Kumar A. A prospective study of sensitivity and specificity of adenosine deaminase estimation in the diagnosis of tuberculosis pleural effusion. Indian J Chest Dis Allied Sci. 2001;43(3)149-55. [Crossref]

17. Parikh P, Odhwani J, Ganagajalia C. Study of 100 cases of pleural effusion with reference to diagnostic approach. Int J Adv Med. $2016 ; 3 ; 328-331$.

DOI: $10.18203 / 2349-3933 . i j a m 20161085$ [Crossref]

18. Reddy $\mathrm{Dj}$, Indira C. Needle biopsy of the parietal pleura in the aetiological diagnosis of pleural effusion. J Indian Med Assoc. 1963;40;6-11. [Crossref]
19. Tandon RK, Mishra SR. Pleural biopsy- Analysis of 81 cases. Indian J Tuberculosis. $1975 ; 22 ; 18$. [Crossref]

20. Mocelin HT, Fischer GB. Epidemiology, presentation and treatment of pleural effusion. Paediat Resp Rev. 2002;3(4)292-297.

DOI: $10.1016 / \mathrm{S} 1526-0542(02) 00269-5$ [Crossref]

21. Light RW, Erozan YS, Ball WC Jr. Cells in pleural fluid, Their value in differential diagnosis. Arch Intern Med. 1973;132(6)854-60.

DOI: $\quad 10.1001 /$ archinte. $\quad 1973.03650120060011$ [Crossref]

22. Ungerer JP, Oosthuizen $\mathrm{HM}$, Retief $\mathrm{JH}$, Bissbort $\mathrm{SH}$. Significance of adenosine deaminase activity and its isoenzymes in tuberculous effusions. Chest. 1994;106(1)33-7.

DOI: $10.1378 /$ chest.106.1.33 [Crossref]

23. Shibagaki T, Hasegawa $Y$, Saito $H$, Yamori $S$, Shimokata K. Adenosine deaminase isozymes in tuberculous pleural effusion. J Lab Clin Med. $1996 ; 127(4) 348-52$.

DOI: 10.1016/S0022-2143(96)90182-1 [Crossref]

24. Khan FY, Alsamawi $M$, Yasin $M$, Ibrahim AS, Hamza $M$, Lingaw $M$ et al. Etiology of pleural effusion among adults in the State of Qatar- a 1-year hospital-based study. East Med Health J. 2011;17(7)611-18.

[Crossref]

25. Noronha V, Dikshit R, Raut N, Joshi A, Pramesh CS, George K. Epidemiology of lung cancer in India: focus on the differences between nonsmokers and smokers- a single-centre experience. Indian J Cancer. 2012;49(1)74-81. DOI: $10.4103 / 0019-509 \times .98925$ [Crossref] 